\title{
Antenatal Acute Toxoplasmosis Diagnosis in First Trimester Pregnancy
}

\author{
Ersin Çintesun ${ }^{1}$, Mete Bertizlioğlu ${ }^{1}$, Uğur Arslan ${ }^{2}$ and Çetin Çelik ${ }^{1}$ \\ 1. Department of Obstetrics and Gynecology, Selcuk University, Konya 42030, Turkey \\ 2. Department of Medical Microbiology, Selcuk University, Konya 42030, Turkey
}

\begin{abstract}
Objectıves: Toxoplasmosis is a widely-distributed zoonosis that is caused by Toxoplasma gondii protozoa. Toxoplasmosis is a high prevalence of unapparent infections, and when infected for the first time during pregnancy, can present a temporary parasitemy with focal lesions generated within the placenta, thereby infecting the fetus. Our aim in this study is to evaluate the patients who have been diagnosed with new toxoplasm in our hospital for six months. Methods: In our study, the toxoplasma results of the first trimester pregnant patients who applied to our polyclinic in the second half of 2016 were evaluated. A total of 391 cases were included in the study. Patients whose laboratory results were not available or under-investigated were excluded from the study. In our policlinic, toxoplasmosis IgM is primarily required in first trimester pregnancies. If positive, IgG and avidity are desired. Further investigation is carried out according to the avidity result. SPSS 22 and Microsoft Excel 2007 program were used in the analysis of our work. Results: A total of 8 (2\%) patients had positive toxoplasmosis IgM, 4 (1\%) patients had high avidity, $1(0.2 \%)$ patients had moderate avidity, and $3(0.7 \%)$ patients had low avidity. Conclusions: There is no consensus on the screening of all pregnancies. Screening of all pregnancies is recommended in places where the general view seroprevalence is high.
\end{abstract}

Key words: Acute toxoplamosis, pregnancy, infection.

\section{Objectives}

Toxoplasmosis is a widely-distributed zoonosis that caused by Toxoplasma gondii protozoa [1, 2]. Toxoplasmosis is a high prevalence of unapparent infections, and when infected for the first time during pregnancy, can present a temporary parasitemy with focal lesions generated within the placenta, thereby infecting the fetus [2]. The incidence of maternal infection during pregnancy ranges from 1 to 8 per 1,000 susceptible pregnancies, with the highest reported rates in France [3]. However, the rate in France has significantly decreased in the past decade; the incidence of Toxoplasma infection was diagnosed by seroconversion in French women was 2.1 per 1,000 in 2010 [4]. Toxoplasma seropositivity rate in our country Region varies from region to region. This rate

Corresponding author: Ersin Çintesun, medical doctor, research fields: obstetrics and gynecology. is higher in eastern cities. The highest rate in our country is the high eating habits of raw meat in Sanliurfa. Our aim in this study is to evaluate the patients who have been diagnosed with new toxoplasm in our hospital for 6 months.

\section{Methods}

In our study, the toxoplasma results of the first trimester pregnant patients who applied to our polyclinic in the second half of 2016 were evaluated. A total of 391 cases were included in the study. Patients whose laboratory results were not available or under-investigated were excluded from the study. In our policlinic, toxoplasmosis IgM is primarily required in first trimester pregnancies. If positive, IgG and avidity are desired. Further investigation is carried out according to the avidity result. SPSS 22 and Microsoft Excel 2007 program were used in the analysis of our work. 
Table 1 Avidity and IgM levels.

\begin{tabular}{lll}
\hline & Number & $\%$ \\
\hline Low avidity & 3 & 0.7 \\
Moderate avidity & 1 & 0.2 \\
High avidity & 4 & 1 \\
Positive toxoplasmosis IgM & 8 & 2 \\
\hline
\end{tabular}

\section{Results}

A total of 8 (2\%) patients had positive toxoplasmosis IgM, 4 (1\%) patients had high avidity, $1(0.2 \%)$ patients had moderate avidity, and $3(0.7 \%)$ patients had low avidity (Table 1).

\section{Discussion}

Toxoplasmosis is a common disease worldwide and in our country [5]. Seroprevalence varies according to age, geographic location, hygienic conditions, life habits, nutritional status, and contact frequency with cats [6]. Toxoplasmosis infection is a lethal disease in immunocompromised individuals, low births and premature birth in the past, and congenital toxoplasmosis in the newborn, so diagnosis must be made correctly and timely [7]. The seroprevalence of Toxoplasma in pregnancies was reported as $39.4 \%$ in the US, $54.4 \%$ in France, $51.1 \%$ in Iran and $45 \%$ in India [8-10].

The seropositivity of Toxoplasma varies according to the regions in our country. In studies, IgM seropositivity was reported in Aydin 2.6\%, in Erzurum 0.4\% and in Diyarbakir 8.16\% [11-14]. In our study, Toxoplasma IgM positivity was found $2 \%$.

\section{Conclusions}

There is no consensus on the screening of all pregnancies. Screening of all pregnancies is recommended in places where the general view seroprevalence is high.

\section{References}

[1] LEVINE, N. D. 1977. "Taxonomy of Toxoplasma.” The Journal of Protozoology 24 (1): 36-41.

[2] Dubey, J. 1977. "Toxoplasma, Hammondia, Besnoitia,
Sarcocystis, and Other Tissue Cyst-Forming Coccidia of Man and Animals.” Parasitic Protozoa 3: 101-237.

[3] Gilbert R. E., Peckham C. S. 2002. "Congenital Toxoplasmosis in the United Kingdom: To Screen or Not to Screen?” Journal of Medical Screening 9 (3): 135-41.

[4] Nogareda, F., Le Strat, Y., Villena, I., De Valk, H., and Goulet, V. 2014. "Incidence and Prevalence of Toxoplasma Gondii Infection in Women in France, 1980-2020: Model-Based Estimation.” Epidemiology and Infection 142 (8): 1661-70.

[5] Tanyüksel, M., Gün, H., Erdal, N., Haznedaroğlu, T., Babür, C., Baysallar, M., et al. 1994. "Toksoplazmosis Tanısında Serolojik Testlerin Karşılaştırılması.” $T$ Parazitol Derg 18 (3): 266-76.

[6] Altıntaş, N., Yolasığmaz, A., Yazar, S., Şakru, N., and Kitapçıŏlu, G. 1998. "İzmir ve çevresindeki Yerleşim Bölgelerinde Yaşayan Insanlarda Toxoplasma Antikorlarının Araştırılması.” T Parazitol Derg 22 (3): 229-32.

[7] İnci, M., Yağmur, G., Aksebzeci, T., Kaya, E., and Yazar, S. 2009. "Kayseri'de Kadınlarda Toxoplasma Gondii Seropozitifliğinin Araştırılması.” Türkiye Parazitoloji Dergisi. 33 (3): 191-4.

[8] Assmar, M., Amirkhani, A., Piazak, N., Hovanesian, A., Kooloobandi, A., and Etessami, R. 1996. "Toxoplasmosis in Iran. Results of a Seroepidemiological Study.” Bulletin de la Societe de pathologie exotique (1990) 90 (1): 19-21.

[9] Nash, J., Chissel, S., Jones, J., Warburton, F., and Verlander, N. 2005. "Risk Factors for Toxoplasmosis in Pregnant Women in Kent, United Kingdom.” Epidemiology and Infection 133 (03): 475-83.

[10] Singh, S., and Pandit, A. J. 2004. "Incidence and Prevalence of Toxoplasmosis in Indian Pregnant Women: A Prospective Study.” American Journal of Reproductive Immunology 52 (4): 276-83.

[11] Gül, K., Dağ, M., Suay, A., Mete, M., and Mete, Ö. 1994. "DÜ Tip Fakültesinin Değişik Bölümlerine Başvuran ve Toxoplasma ön Tanısı Konmuş Hastalarda Toxoplasma Antikorlarının Dağılımı.” Türkiye Parazitol Derg. 18 (4): 394-7.

[12] Köksal, İ., Aynacı, M., Kardeş, B., Aydemir, V. 1994. "Doğu Karadeniz bölgesi'nde erişkin yaş grubunda 
Toksoplazma, Kızamıkçık ve Sitomegalovirüs seropozitiflik oranları.” Mikrobiyol Bül 28 (1): 58-66.

[13] Yiğit, N., Aktaş, A., Uslu, H., Aydın, F., and Babacan, M. 2000. “Atatürk Üniversitesi Tip Fakültesi Mikrobiyoloji Laboratuvarına Gelen Toxoplasmosis şüpheli Hasta
Serumlarında Toxoplasma Gondii Antikorlarının Araştırılması.” Türkiye Parazitol Derg 24 (1): 22-4.

[14] Yazar, S., Altunoluk, B., Akman, M., Şahin, İ. 2000. "Gebelerde Anti-toxoplasma Gondii Antikorlarının Araştırılması.” Türkiye Parazitol Derg 24 (4): 343-5. 